\title{
Shrimp Post-Larvae Nursing in Earthen Ponds, Bangladesh
}

\author{
M. Jannat ${ }^{1}$, M. K. Ahmed ${ }^{2}$, M. M. Islam ${ }^{1} *$ G. K. Kundu ${ }^{1}$, M. Kamruzzaman ${ }^{3}$ \\ ${ }^{1}$ Department of Fisheries, University of Dhaka, Dhaka-1000, Bangladesh \\ ${ }^{2}$ Department of Oceanography, University of Dhaka, Dhaka-1000, Bangladesh \\ ${ }^{3}$ Department of Fisheries, Ministry of Fisheries and Livestock, Government of the People's \\ Republic of Bangladesh
}

Received 24 June 2016, accepted in final revised form 23 October 2016

\begin{abstract}
In Bangladesh, shrimp post-larvae (PL) are mainly produced in hatcheries. From 2000s shrimp PL are reared in nurseries containing small earthen ponds by relatively poor people for a few days before stocking into the shrimp farms. This study assesses the physical and chemical parameters of five such nurseries at Satkhira district, Bangladesh using scientific instruments and semi-structured questionnaire. The nursing process involved stocking of PL $\left(4151.8 \pm 1581.35 \mathrm{PL} / \mathrm{m}^{2}\right)$ in small earthen ponds $\left(<18 \mathrm{~m}^{2}\right.$ area/pond $)$ and raring for up to 10 days with feeding. Most of the physico-chemical parameters were within the suitable range recommended for shrimp culture. The survival rate of PL ranged from $80 \%$ to $90 \%$. The nursing system was profitable as the average Benefit-Cost Ratio (BCR) was 1.19. The establishment and operation of these nurseries do not require any expensive equipment or complex technology and can be run by less educated and poor people. However, constraints like lack of credit and continuous water supply are hindering the scaling up of these nurseries in size and number. By providing means to overcome the constraints these nurseries can be an excellent income generating source for the poor entrepreneurs as well as contribute in increasing shrimp production in Bangladesh.
\end{abstract}

Keywords: Shrimp post-larvae; Nursing system; Shrimp farming; Poor entrepreneur.

(C) 2017 JSR Publications. ISSN: 2070-0237 (Print); 2070-0245 (Online). All rights reserved. doi: http://dx.doi.org/10.3329/jsr.v9i1.28482 J. Sci. Res. 9 (1), 97-107 (2017)

\section{Introduction}

The brackish water shrimp culture in Bangladesh has expanded rapidly over the past thirty years [1] and involves around 833,000 people in coastal farming and many more in different stages of farming to marketing [2]. The country is an important contributor in the global cultured shrimp industry exporting $97 \%$ of its total production [3]. Shrimp is the third highest (1.8\% of total export earnings excluding the EPZs) export earning commodity in the country which earned US\$506 million in 2014-2015 from exporting

* Corresponding author: monirulislam153@yahoo.com 
prawn and shrimp [4]. It produced 223788 metric tons of shrimp and prawn in 2013/2014 of which $57.34 \%$ came from shrimp farms [5].

Shrimp farming sector is very diverse in cultured species and farming systems in Bangladesh. The black tiger shrimp (Penaeus monodon), locally known as bagda is cultured predominantly under extensive farming systems, which are characterized by low stocking densities $\left(1-2 \mathrm{PL} / \mathrm{m}^{2}\right)$, use of little or no external inputs and tidal water exchange [6,7]. Bagda farms (locally known as ghers) are created mainly by transforming the rice fields or fallow lands and the area varies in size from 0.4 to 200 ha [8]. Farmers start stocking during the winter months (November to February). In the 2000s, the shrimp farmers used to depend mostly on the wild post-larvae (PL) collected from the coastal areas for stocking in ghers. Intensification of culture in existing farms and construction of many new farms have increased the demand for the PL. In order to meet the increasing demand many shrimp hatcheries (60 in 2013) have been established. On the other hand, wild shrimp PL collection is prohibited in order to protect the ecosystems. Nearly $80 \%$ of the shrimp PL produced in the hatcheries that produced 9239.2 million PL in 2012/13 [9]. Most of the shrimp hatcheries are located in the south-east zone (Chittagong division) of Bangladesh, while about $90 \%$ of the wild shrimp PL are caught in the same zone [10]. In contrast, approximately $80 \%$ of the total shrimp farms are in the south-west zone (Khulna division), mainly in Satkhira, Khulna and Bagerhat district [6]. The PL are thus transported a long distance from south-east to south-west. In early 2000s the PL $(2-3 \mathrm{~cm})$ were stocked directly to shrimp ponds after transportation from hatcheries resulting in high mortality due to poor acclimatization and predation [11]. In mid 2000s, farmers started stocking the transported PL in small nurseries before stocking into ghers to reduce the post-stocking mortality. These nurseries were cemented tanks or earthen ponds where the new PL could adapt to local environmental conditions such as temperature, salinity and $\mathrm{pH}$ of the water. However, the mortality still results in financial loss to shrimp farmers.

In south-west Bangladesh, some people have developed a new indigenous technique for shrimp PL nursing where they nurse the shrimp PL in very small earthen ponds for few days to acclimatize the PL after transportation. The acclimatized PL is then sold at a higher price than non-acclimatized ones. These outdoor earthen pond nurseries typically operate only during the shrimp stocking season. Workers at nurseries reported that their nurtured PL have significantly higher survival rates (up to $100 \%$ in some cases). This nursery is an advantageous than the conventional indoor nursing facilities in hatcheries. This is because this new nurseries are established locally and the shrimp PL are reared in local environment. This increase the survival rate and the shrimp farmers also prefer to buy PL from local earthen-nursery than those from fish traders or directly from hatchery. Moreover, the establishment of conventional indoor nurseries made of cemented tanks in hatchery is expensive. So, only rich people can afford the capital investment. In contrast, the earthen pond nursery can be established by poor entrepreneur. Thus scaling up of this indigenous nursing technique can improve the shrimp farming practice along with creating new income source for poor villagers. Before going for scaling up initiative 
detailed information on requirements, processes, returns and constraints of these nurseries are required. But study on status and its potential this type of nursery has not been reported yet. Therefore, the present study was first attempt to explore the structural features, physic-chemical characteristics and cost-benefit analysis of the earthen pond nurseries of shrimp PL. The study was carried out with a view to assessing the emergence of this new indigenous technique for the poor entrepreneur in south-west Bangladesh and also to other developing countries where poor farmers are the major part of the shrimp farming process.

\section{Materials and Methods}

The study was conducted in five randomly selected earthen pond nurseries at Satkhira sadar upazilla of Satkhira district which is located in the southwest Bangladesh (Fig. 1). The similarities and differences among the nurseries studied in their ways of nursing and their output made the findings more compelling and offered a chance to learn from comparative case study research. These findings will therefore help find ways to improve the nursing technique not only for increasing shrimp production but also for the improvement of livelihoods of small-entrepreneur.

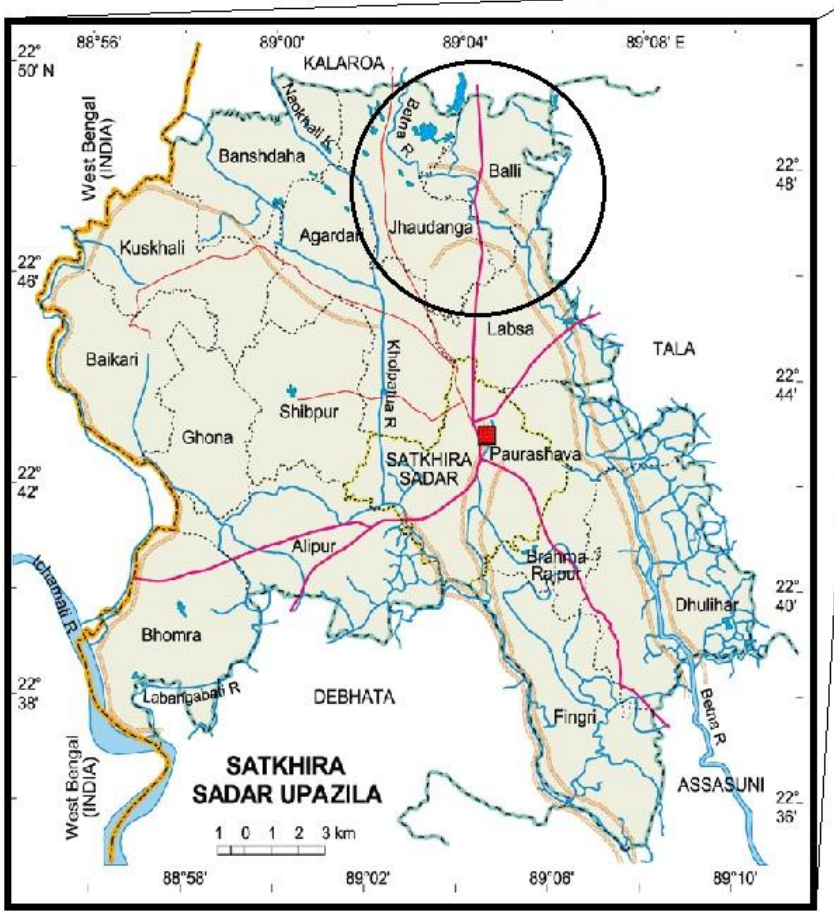

Fig. 1. The study area (in circle). 
Nursery owners and permanent laborers of the selected nurseries were interviewed, using semi-structured questionnaire. Data were collected on structural features of the nursery, pond characteristics, nursing process (e.g. stocking, feeding, nursing duration, etc.), cost and benefit. A total of 40 respondents ( 8 in each nursery) were interviewed out in these nurseries. Each interview lasted for 1-1.5 h.

Water salinity of different nurseries was measured using a hand refractometer (HANNA: HI 9142, USA). The soil and water $\mathrm{pH}$ was measured using a $\mathrm{pH}$ meter (Model- 3150, JENWAY-U.K.). The pond soil texture was estimated by bottle test and the soil type was calculated using the triangular diagram according to USDA particle sizes [12].

The quantitative data were analysed using Microsoft Excel program and results were presented in mean \pm standard deviation. The qualitative data obtained through interviews were analysed by content analysis after data coding.

\section{Results and Discussion}

\subsection{Structural features of nursery}

The earthen pond nurseries were constructed in an area where the environment (especially water quality) was very close to that of the shrimp ponds. Each nursery was a collection of 3-5 small earthen nursing ponds arranged in a series. There were reserve ponds for storing water alongside the nursing ponds. A schematic layout of structural features of a nursery studied is presented in Fig. 2. The width of the dykes in between two adjacent nursing ponds was $0.5-0.6 \mathrm{~m}$. The nursery labourers told that these dykes were used as pavement which helped in monitoring (e.g., observing water depth, movement of PL, etc.) and management (e.g., feeding, removing waste, etc.) of ponds. The other two dykes were wider $(0.8-1.0 \mathrm{~m})$ which gave the ponds stability. All the ponds were enclosed within a house; the side walls of which are made of bamboo fence (Fig. 2) that provided protection from outside. The ponds were protected further with roof made of straw and covered with polythene to protect from rainfall and excess sunlight. This house turns the whole nursing facility indoor which minimizes the impact of environmental variability like, change in temperature, rainfall, etc. which in turn prevents the shrimp PL form sudden shock.

The structural features of the nursing ponds are presented in Table 1. Since the ponds were small in size $\left(96-18 \mathrm{~m}^{2}\right)$ the establishment of a nursery required relatively small land area $\left(330-660 \mathrm{~m}^{2}\right)$. The pond depth is an important parameter for PL survival. Water temperature of a shallow pond changes quickly which results in high mortality of PL in sunny summer days. In contrast deeper ponds require higher volume of water which requires more labour and expenses. The nursing ponds were shallower than the recommended water depth $(0.8$ to $1.2 \mathrm{~m})$ for shrimp farming [13]. The impact of shallower water is probably compensated by the external coverings (roof) of the hatcheries which protect from heat and rainfall. 


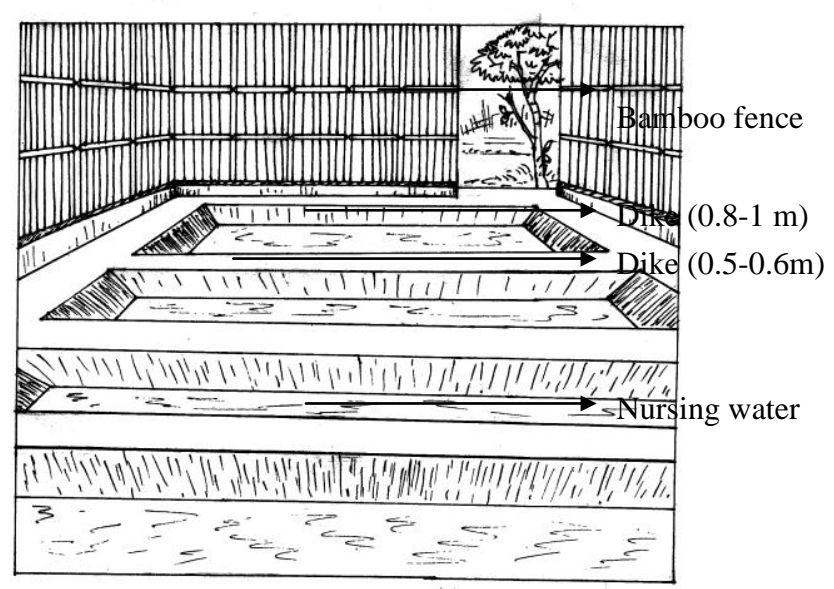

Fig. 2. A Schematic layout of an earthen pond nursery of shrimp PL at Satkhira.

Table 1. Nursing area, water depth, water $\mathrm{pH}$, water salinity, and soil $\mathrm{pH}$ of the earthen pond nurseries for shrimp PL at Satkhira.

\begin{tabular}{llllllll}
\hline $\begin{array}{l}\text { Nursery } \\
\text { Number }\end{array}$ & $\begin{array}{l}\text { No of pond } \\
\text { in each } \\
\text { nursery }\end{array}$ & $\begin{array}{l}\text { Size of } \\
\text { individual } \\
\text { pond }(\mathrm{m} \times \mathrm{m})\end{array}$ & $\begin{array}{l}\text { Total } \\
\text { nursing } \\
\text { area }\left(\mathrm{m}^{2}\right)\end{array}$ & $\begin{array}{l}\text { Water } \\
\text { depth of } \\
\text { pond }(\mathrm{m})\end{array}$ & $\begin{array}{l}\text { Pond water } \\
\text { salinity } \\
(\mathrm{ppt})\end{array}$ & $\begin{array}{l}\text { Pond } \\
\text { Water } \\
\mathrm{pH}\end{array}$ & $\begin{array}{l}\text { Pond } \\
\text { Soil } \\
\mathrm{pH}\end{array}$ \\
\hline 1 & 5 & $4 \times 2$ & 660 & 0.8 & 10 & 7.0 & 7.5 \\
2 & 4 & $4 \times 3$ & 462 & 0.8 & 11 & 7.2 & 7.8 \\
3 & 4 & $3 \times 2$ & 400 & 0.6 & 8 & 7.3 & 7.6 \\
4 & 3 & $3 \times 3$ & 330 & 0.6 & 7 & 7.5 & 7.2 \\
5 & 4 & $6 \times 3$ & 330 & 0.6 & 5 & 7.1 & 7.5 \\
\hline Mean \pm & 4 & - & $436 \pm$ & $0.68 \pm$ & $10.25 \pm$ & $7.2 \pm$ & $7.5 \pm$ \\
SD & & & 137 & 0.11 & 3.3 & 0.19 & 0.22 \\
\hline
\end{tabular}

\subsection{Water supply in the nurseries}

The only source of water of these nurseries was the nearby Betna River. The nurseries stored river water were in reserve ponds before draining into nursing ponds. This helped in settling down excess suspended material from water and also helped during inconsistent water supply in river. However, in some nurseries water was directly pumped into nursing pond in both cases, a fine meshed net were used at the mouth of inlet pipe during water supply to filter any large physical object present in the water.

\subsection{Soil and water qualities of nursery}

Salinity is an important water quality parameter for shrimp farming. The soil salinity was not measured in the present study with an assumption that it will not have any significant impact on water salinity as the source of water was nearby river (discussed in later section). Salinity of nursing pond water ranged from 5 to $11 \mathrm{ppt}$ (Table 1) which was 
compatible with the average salinity of shrimp farm. The shrimp PL are reared at high salinity ( $>25 \mathrm{ppt}$ ) in hatcheries which is also used by the PL traders during transportation. On the other hand, 10 to $35 \mathrm{ppt}$ water salinity is suitable for shrimp culture [14]. Although, shrimp has been grown profitably in the ponds with salinity ranged from 6 to 11 ppt. [15]. So, the average salinity of shrimp ghers is much lower than the hatchery or transport bags. In nursery the PL gradually acclimatize to lower salinity which prevents the PL from shock of sudden large variation in salinity. The water and soil $\mathrm{pH}$ ranged from 7.0-7.5 and 7.2 -7.8 respectively which is within the suitable range recommended for shrimp culture [16]. The pond soil type was silty-loam with approximate proportion of $17 \%, 62 \%$ and $21 \%$ of sand, silt and clay respectively. Silty-loam has good productivity and suitable for shrimp farming [17]. This type of soil is also good for dyke construction [18]. So, the soil type was suitable in this regard as well. However, the water retention capacity of silty-loam is moderate. The ponds were excavated by removing soil as stated by the respondents. The pond bottom was sealed smoothly with soil before filling it with water which prevented water loss by seepage.

\subsection{The nursing system}

\subsubsection{Nursing pond preparation}

For the pre-stocking management in nursing ponds, quick lime $\left(\mathrm{Ca}(\mathrm{OH})_{2}\right)$ was used at the rate of 0.1 to $2.5 \mathrm{~g} / \mathrm{m}^{2}$. No organic and inorganic fertilizer was used.

\subsubsection{PL acclimatization and stocking}

The nursery owners bought PL from local fish traders. Before stocking to nursing ponds the nursers judged the water salinity by oral testing. If the salinity of transporting water seemed to be too higher than that of nursing pond, the PL was taken out from the transport water in a scoop net and held into a bowl containing the low saline nursing pond water. After acclimatization for about half an hour, the PL was stocked in nursing ponds at varying densities ranging from 2579 to $6010 \mathrm{PL} / \mathrm{m}^{2}$ (Table 2). The stocking density is many times higher than that of a semi-intensive shrimp farm in Bangladesh where 10-35 $\mathrm{PL} / \mathrm{m}^{2}$ are stocked [19].

Table 2. Stocking density (PL/ $\mathrm{m}^{2}$ ) and nursing duration (days) of shrimp PL in earthen pond nurseries at Satkhira.

\begin{tabular}{lll}
\hline Nursery Number & Stocking density $\left(\mathrm{PL} / \mathrm{m}^{2}\right)$ & Nursing duration (days) \\
\hline 1 & 6010 & $3-5$ \\
2 & 4000 & $3-5$ \\
3 & 5507 & $3-10$ \\
1 & 2663 & $2-5$ \\
5 & 2579 & $4-5$ \\
\hline Mean \pm SD & $4151.8 \pm 1581.35$ & -
\end{tabular}




\subsubsection{Feeding}

The stocked PL were fully dependent on supplementary feeding except in one nursery. So, no fertilizer or chemical was used after stocking PL in the nursery ponds. Both commercial and homemade feed were used (Table 3). The commercial feed was a mixture of different nutrients and vitamins for bagda which were made in Japan (Deoxidized Pack, Higashimaru Co. Ltd.). Protein was the principal component in both type of feed used as the PL required high \% protein for growth. The composition of moisture, crude protein and fat in the commercial feed were 10, 48 and $8 \%$ respectively. This feed was given at $0.12-0.2 \mathrm{~g} / \mathrm{m}^{2}$ pond area. However, boiled egg yolk was given as the homemade feed at $1 \mathrm{egg}$ yolk/ $6 \mathrm{~m}^{2}$.

Table 3. Liming doses and feeding of shrimp PL in earthen pond nurseries at Satkhira.

\begin{tabular}{lllll}
\hline $\begin{array}{l}\text { Nursery } \\
\text { number }\end{array}$ & $\begin{array}{l}\text { Pre-stocking } \\
\text { liming }\left(\mathrm{g} / \mathrm{m}^{2}\right)\end{array}$ & Type of feed & $\begin{array}{l}\text { Cost of } \\
\text { feed }(\mathrm{TK} / \mathrm{Kg})\end{array}$ & Feeding rate \\
\hline 1 & 2.4 & Commercial & 500 & 2 times a day at $0.2 \mathrm{~g} / \mathrm{m}^{2}$ \\
2 & 2.0 & Commercial & 500 & $0.2 \mathrm{~g} / \mathrm{m}^{2}$ \\
3 & 13.0 & Boiled egg & $4 / \mathrm{egg}$ & $\begin{array}{l}\text { time a day } 1 \mathrm{egg} / 6 \mathrm{~m}^{2} \text { sized } \\
\text { pond }\end{array}$ \\
4 & 7.0 & No feed & - & - \\
5 & 0.1 & Commercial & 500 & 2 times a day at $0.12 \mathrm{~g} / \mathrm{m}^{2}$ \\
\hline
\end{tabular}

\subsubsection{Harvesting}

Although sell started after 3 days of nursing, the nursing period ranged between 2-10 days (Table 2). The shortest nursing duration was of 2 days where no feeding was given (Table 3). PL was stocked for short term acclimatization at very low density (Table 2). PL was harvested by scoop net.

\subsubsection{Survival rate of $P L$}

The mean survival rate was $85.6 \%$ and ranged from $80 \%-90 \%$ in the nurseries studied (Fig. 3). The lowest survival rate was $80 \%$ in a nursery where PL was not fed during the nursing period. The result in the above mentioned study was based on 90 days rearing. Although studies reported shrimp PL nursing as a means of improving survival rate before stocking in rearing ponds for 15 to 25 days in net enclosures installed in pond or permanent nursing ponds [19,20], but no survival rate was reported. However, Islam et al. [21] reported that that short time in-pond nursery of PL significantly $(\mathrm{p}<0.05)$ improved the survival rate $(58 \%)$ from direct stocking of PL $(47.81 \%)$ in the rearing pond in a 90 day rearing of $P$. monodon. In Bangladesh, the survival rate of shrimp in semi-intensive and traditional or extensive rearing system was 70.5 and $15.5 \%$, respectively [19]. 


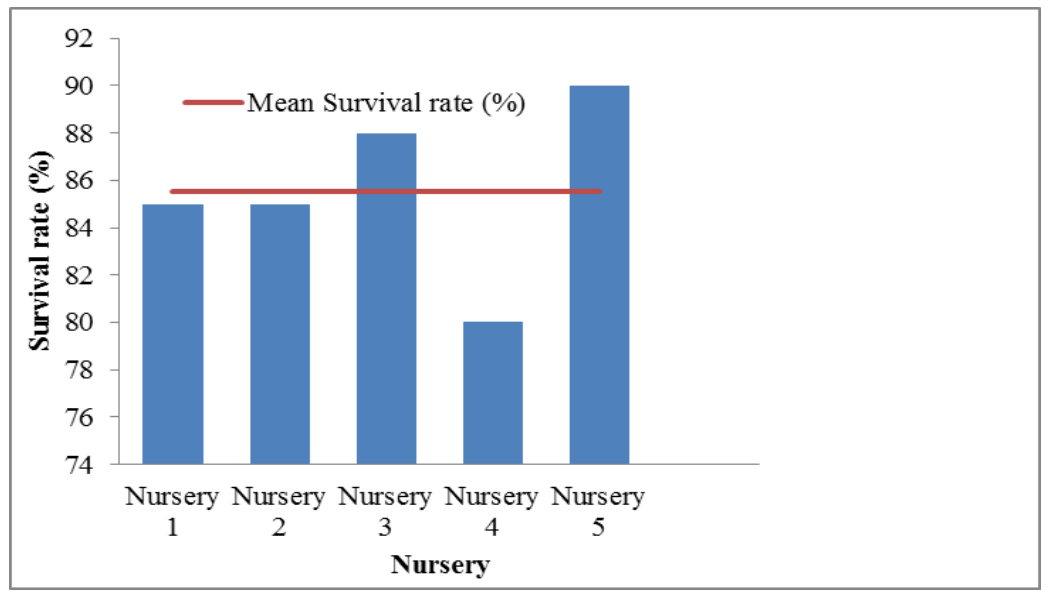

Fig. 3. Survival rate (\%) of shrimp PL in earthen pond nursery at Satkhira.

\subsection{Cost-benefit analysis of nursery}

The Benefit-Cost Ratio (BCR) was calculated to evaluate the profitability of nurseries (Table 4). Since all the nurseries in the present study were constructed on the own land of nursery owner, there was no land cost. So, the BCR was calculated without considering the construction cost. The cost of construction of infrastructure containing 3-5 ponds excluding the land cost was $15,000-20,000$ TK (1 US\$ = 77.75 TK). All the construction materials were readily available in the local area and were relatively inexpensive. The respondents stated that, once the infrastructure was made it could be used for 4-5 years. The nursery infrastructures and ponds are monitored regularly. Each year it is repaired. The variable costs were needed throughout the nursing duration and beyond.

Table 4. Cost-benefit analysis of the earthen pond nurseries of shrimp PL at Satkhira.

\begin{tabular}{llllllll}
\hline \multirow{2}{*}{$\begin{array}{l}\text { Nursery } \\
\text { number }\end{array}$} & \multicolumn{2}{l}{ Cost $\left(\mathrm{TK} / \mathrm{m}^{2}\right)^{1}$} & & $\begin{array}{l}\text { Total cost } \\
\left(\mathrm{TK} / \mathrm{m}^{2}\right)\end{array}$ & $\begin{array}{l}\text { Income } \\
\left(\mathrm{TK} / \mathrm{m}^{2}\right)\end{array}$ & $\begin{array}{l}\text { Profit } \\
\left(\mathrm{TK} / \mathrm{m}^{2}\right)\end{array}$ & $\begin{array}{l}\text { Benefit- } \\
\text { cost ratio }\end{array}$ \\
\cline { 2 - 6 } & stocking & Stocking & $\begin{array}{l}\text { Post- } \\
\text { stocking }\end{array}$ & & & & \\
\hline 1 & 0.34 & 2116 & 0.52 & 2117 & 2555 & 438 & 1.21 \\
2 & 0.44 & 1408 & 0.66 & 1409 & 1700 & 291 & 1.21 \\
3 & 0.14 & 2214 & 0.55 & 2215 & 2665 & 450 & 1.20 \\
4 & 0 & 812 & 0 & 812 & 852 & 40 & 1.05 \\
5 & 1.45 & 1167 & 0.23 & 1171 & 1393 & 223 & 1.10 \\
Mean & 0.474 & 1543.4 & 0.392 & 1544.8 & 1833 & 288.4 & 1.15 \\
$\pm \mathrm{SD}$ & \pm 0.57 & \pm 606.74 & \pm 0.27 & \pm 606.58 & \pm 772.52 & \pm 169.17 & \pm 0.07 \\
\hline
\end{tabular}

${ }^{1}$ Detailed item costs are not shown here but has explained inside the text - see section 3.5. 
Pre-stocking costs included lime $(10 \mathrm{TK} / \mathrm{Kg})$ and labor. Stocking costs include cost of PL (300-450 TK/1000 PL) and transportation. Post- stocking management included cost of feed (for commercial feed: $500 \mathrm{TK} / \mathrm{kg}$ and for egg yolk: $4 \mathrm{TK} / \mathrm{egg}$ ) and management cost (e.g., hiring labour, buying cleaning materials etc.). There was no labor cost in some nurseries (nursery 3 and 4 ) because the nursing activities were done by their own family members and the nursery was adjacent to their home. Income was calculated from selling price of PL (400-600 TK/1000 PL). Usually the selling price of 1000 PL was 100-150 TK more than the purchase price. The profit from the each nursery varied (Table 4). No nursery encountered any loss and the profit was very high since the PL were started to sell within few days after stocking. Although there was great variation in per unit cost of different variables, there was minor variation in BCR (Table 4). The average BCR of the five nurseries was 1.15 . The lowest BCR was found in nursery 4 . This was probably due to higher mortality as a result of no liming and no feeding.

\subsection{Constraints toward expansion of earthen pond nursing technique}

The study identified some constraints of earthen pond nursery. Although the establishment of this type of nursery requires only 15,000-20,000TK (except land cost), it is still unaffordable for many poor people in southwest Bangladesh. The interviews revealed that lack of credit was the prominent constraint especially for pro-poor entrepreneurs. On the other hand, the relatively less poor entrepreneur did not have enough credit to run the nursery in a larger scale. The lack of access to credit hinders the potentiality of producing more acclimatized PL from earthen nurseries. Lack of continuous water supply to earthen nursery, especially during the dry season was another constraint. Storing more water in reserve ponds requires more capital investment.

\subsection{Emergence of earthen nursing as a new technology}

In Bangladesh, shrimp culture firms, hatcheries, nurseries and processing plants are owned by relatively richer people as they require a lot of investments $(0.2$ million to 80 million Taka). The earthen nursery is an exception which requires much less investment $\mathrm{s}$ as mentioned above. It is an exceptional opportunity for relatively poor people with little technical skills and educational quality to become an entrepreneur in this sector which will help increase production. Besides low investment, the shrimp nursing has emerged as a new indigenous technology by small-scale entrepreneur due to the following reasons:

i) Method of acclimatization: Shrimp PL which are bought for stocking in ponds are stocked in high densities in earthen nursery for few days. This helps them survive in new environment successfully. For this the water quality and other environmental conditions of earthen pond nursery are almost the same as traditional ponds. This provides greater rate of PL survival.

ii) Place of dumping: Earthen nursery is also used as a place of dumping of PL. Sometimes, the excess amount of shrimp PL which are not sold in due time are held in 
this earthen pond nursery for selling them later. There is another reason that the fish traders buy a lot of shrimp PL at low price when they are available and do nursing for a few days. This low price of PL prompts the hatchery owner to supply less PL in the Satkhira area. This usually creates a shortage of PL after 1 or 2 weeks. The earthen nursery owners take advantage of this situation and sell their PL which meanwhile had adapted to local environment. In this situation, the nursery owners sell their PL at higher rate.

\section{Conclusions}

This study reveals the potentiality of earthen pond nurseries as a means of increased availability of better surviving shrimp PL, increased profitability and involvement of poor entrepreneurs in southwest Bangladesh. These nurseries currently have been facing some constraints such as lack of credit and continuous supply of water, which need to be resolved to exploit the potential of this low-cost indigenous nursing technique. This study is the first attempt to characterize the earthen pond nursery. More in depth study needs to be done on economic viability and social consequences of these nurseries before going for scaling up the technique in other areas.

\section{References}

1. M. I. M. Shameem, S. Momtaz, and A. S. Kiem, Climatic Change 133, 253 (2015). http://dx.doi.org/10.1007/s10584-015-1470-7

2. N. Ahmed, Ocean Coastal Management 75, 33 (2013). http://dx.doi.org/10.1016/j.ocecoaman.2013.01.002

3. F. Kruijssen, I. Kelling, H. Meechee, K. Jespersen, and S. Ponte, Value Chains of Selected Aquatic Products from Four Asian Countries. A Review of Literature and Secondary Data (World Fish, Penang, Malaysia, 2012).

4. FRSS, Fisheries Statistical Report of Bangladesh, Fisheries Resources Survey System, (Department of Fisheries, Bangladesh, 2016).

5. DoF, National Fish Week, Compendium (in Bengali), (Department of Fisheries, Ministry of Fisheries and Livestock, Bangladesh, 2015) pp.130.

6. A. Begum and S. M. N. Alam, Social and Economic Impacts of Shrimp Sisease among SmallScale, Coastal Farmers and Communities in Bangladesh. In: Arthur JR, Phillips MJR, Subasinghe P, Reantaso MB, MacRae IH, editors. Primary Aquatic Animal Health Care in Rural, Small-scale, Aquaculture Development, (FAO Fisheries Technical Paper. No. 406, 2002). pp.191-200.

7. M. A. Wahab, A. Bergheim, and B. Braaten, Aquaculture 218(1), 413 (2003). http://dx.doi.org/10.1016/S0044-8486(03)00009-7

8. M. S. Islam, A. Milstein, M. A. Wahab, A. H. M. Kamal, and S. Dewan, Aquaculture Int. 13(6), 489 (2005). http://dx.doi.org/10.1007/s10499-005-9000-7

9. FRSS, Fisheries Statistical Report of Bangladesh (Department of Fisheries, Ministry of Fisheries and Livestock, Bangladesh, 2014) 30, pp. 52.

10. S. K. Gammage, M. Swanberg, M. Khondkar, M. Z. Hassan, M. Zobair, and A. M. Muzareba, A Gendered Analysis of the Shrimp Sector in Bangladesh, Development and Training Services (United States Agency for International Development (USAID), Bangladesh, 2006).

11. M. Nuruzzaman, Dynamics and Diversity of Shrimp Farming in Bangladesh Technical Aspect, Shrimp Farming and Industry (BCAS/UPL, Dhaka, Bangladesh, 2006). pp.431-460. 
12. A. G. Coche, Soil and Freshwater Fish Culture-Simple Methods for Aquaculture (Food and Agriculture Organization of the UN, Rome, Italy, 1986).

13. P. Kungvankij, and T. E. Chua. Shrimp Culture, Pond Design, Operation and Management (NACA Training Manual Series No. 2, 1986).

14. BAFRU (Bangladesh Aquaculture and Fisheries Resources Unit) A guide to Shrimp and Prawn Culture in Bangladesh (ODA, UK, 1990).

15. M. M. Islam, K. A. Ahmed, A. M. Shahid, S. Hoque, and D. Islam, J. NOAMI 22, 61 (2005).

16. M. A. Salam and L. G. Ross, (GIS2000, Canada, 2000) pp. 13-16

17. C. E. Boyd- Proc. of the Special Session on Shrimp Farming ed. J. Wyban (1992) pp.166-181.

18. P. Kungvankij, T. E. Chua, B. J. Jr. Pudadera, K. G. Corre, E. Borlongan, L. B. Jr. Tiro, I. O. Potestas, and G. A. Talean, Shrimp culture: pond design, operation and management (NACA Training Manual Series No. 2, 1986).

19. M. Karim and Q. A. Kudrat-E-Kabir. Sci. Technol. 3(1), 1 (2013).

20. M. Washim, PhD. thesis, Bangladesh Agricultural University, Mymenshing, Bangladesh (2014).

21. M. L. Islam and M. J. Alam, Prog. Agricult. 19(2), 167-175 (2008). 